Article

\title{
Pituitary, Gonadal, Thyroid Hormones and Endocrine Disruptors in Pre and Postmenopausal Nigerian Women with ER-, PR- and HER-2-Positive and Negative Breast Cancers
}

\author{
Olulope Ajayi ${ }^{1, *,+}{ }^{(\mathbb{D})}$, Mabel Charles-Davies ${ }^{1}$, John Anetor ${ }^{1}$ and Adeyinka Ademola ${ }^{2}$ \\ 1 Department of Chemical Pathology, College of Medicine, University of Ibadan, Ibadan 200212, Nigeria; \\ mcharlesdavies@yahoo.com (M.C.-D.); johnanetor@gmail.com (J.A.) \\ 2 Division of Surgical Oncology, Department of Surgery, University College Hospital, Ibadan 200212, Nigeria; \\ deoluyinka@yahoo.com \\ * Correspondence: olufema01@yahoo.co.uk or olulope.olufemi@edouniversity.edu.ng \\ + Present address: Department of Biochemistry, Edo University Iyamho, Edo State 312101, Nigeria.
}

Received: 17 April 2018; Accepted: 15 May 2018; Published: 18 May 2018

\begin{abstract}
Breast cancer is broadly sub-divided into hormone responsive and non-hormone responsive subtypes. Estradiol has been associated with hormone responsive breast cancers. There is, however, a paucity of information on the role of sex hormones, gonadotropins, and thyroid hormone in non-hormone responsive breast cancer. This study aimed to determine differences in the serum levels of sex hormones, gonadotropins, thyroid hormones, and endocrine disruptors (lead, cadmium, and arsenic) in Nigerian women with hormone responsive and non-hormone responsive breast cancers. Seventy-nine non-pregnant women aged 28-80 years with histologically confirmed breast cancer were recruited, pre-therapy, into this cross-sectional study. They comprised 52 premenopausal women and 27 postmenopausal women recruited from the Surgical Oncology Clinic of the Department of Surgery, University College Hospital, Ibadan. Comparison of biochemical parameters were based on the positivity $(+)$ and negativity $(-)$ of estrogen receptor (ER), progesterone receptor (PR) and human epithelial receptor-2 (HER-2). Estradiol, progesterone, follicle stimulating hormone $(\mathrm{FSH})$, luteinizing hormone $(\mathrm{LH})$, free thyroxine $\left(\mathrm{FT}_{4}\right)$, free triiodothyronine $\left(\mathrm{FT}_{3}\right)$, and thyroid stimulating hormone (TSH) were determined using enzyme immunoassay (EIA). Serum lead, cadmium and arsenic were determined using atomic absorption spectrophotometry (AAS). Expression of ER, PR and HER2 were determined using immunohistochemistry. Data was analyzed using Mann-Whitney $U$-test and multiple regression, with $p<0.05$ considered as being statistically significant. Estradiol and progesterone were significantly higher in breast cancer participants with $\mathrm{ER}^{-}$and $\mathrm{PR}^{-}$compared with those with $\mathrm{ER}^{+}$and $\mathrm{PR}^{+}$breast cancer $(p<0.05)$. Follicle stimulating hormone and LH levels were significantly higher in participants with $\mathrm{ER}^{+}$and $\mathrm{PR}^{+}$breast cancer compared with participants with $\mathrm{ER}^{-}$and $\mathrm{PR}^{-}$breast cancer $(p<0.05)$. Arsenic was inversely related with TSH in premenopausal participants with $\mathrm{ER}^{-}$and $\mathrm{PR}^{-}(\beta=-0.305 ; \beta=-0.304$, respectively). Sex hormones and gonadotropins appear to be involved in the pathogenesis of triple negative and luminal breast cancer, respectively.
\end{abstract}

Keywords: breast cancer; reproductive hormones; estrogen receptor; progesterone receptor; human epithelial receptor-2 


\section{Introduction}

Breast cancer is a multifaceted disease with distinct biological subtypes. It presents with a varied spectrum of clinical, pathologic, and molecular features, with different prognostic and therapeutic implications [1]. Clinicians rely on traditional clinico-pathological, and readily available, tumor markers such as estrogen receptor (ER), progesterone receptor (PR), and human epithelial receptor-2 (HER-2) because they are reliable, inexpensive, and useful for therapeutic decision making. This makes them a reasonable substitute for other, more expensive, molecular sub-typing tools $[2,3]$. These receptors provide a means by which specific ligands bind resulting in transformation of the inactive oligomeric complex into an active state that regulates gene expression $[4,5]$.

Hormones are considered to be important in the etiology of breast cancer. High levels of estrogens have been associated with breast carcinogenesis [6]. Alkylation of cellular molecules, generation of active radicals, and genotoxicity of estrogen metabolites are reportedly involved in the initiation, promotion, and progression of breast cancer [7-9].

The role of progesterone in breast cancer is controversial. It is thought that it increases breast cancer risk in premenopausal women at the luteal phase. Breast mitotic rates are highest in the luteal phase of the menstrual cycle $[6,10]$. Follicle stimulating hormone (FSH) stimulates follicle growth and development in the ovaries and has been associated with certain cancers including breast cancer [11]. Some reports showed that FSH induces cancer cell proliferation, differentiation, and metastasis by activating adenylyl cyclase, which results in increased cyclic adenosine monophosphate(cAMP) levels $[12,13]$. There is currently a paucity of information on the association of gonadotropins with hormone receptor-positive and negative breast cancer in women with breast cancer in Sub-Saharan Africa. Furthermore, the relationship between thyroid hormones and breast cancer is not clearly defined. Some studies observed that thyroid diseases are common in women with breast cancer, while some had contrary reports $[14,15]$.

Toxic metals, such as lead, cadmium, and arsenic, are a major source of oxidative stress, which is implicated in the development of breast cancer [16]. The differential roles of the toxic metals in the pathogenesis and course of hormone responsive and non-hormone responsive breast cancers are poorly understood. At present, information on the serum levels of pituitary, gonadal, thyroid hormones, and endocrine disruptors in Nigerian women with ER-, PR-, HER-2-positive (+) and negative (-) breast cancers are sparse. Therefore, this study was carried out to compare serum levels of pituitary, gonadal, and thyroid hormones in premenopausal and postmenopausal Nigerian breast cancer participants with positive and negative ER, PR and HER-2.

\section{Materials and Methods}

\subsection{Study Design and Participants}

The study was a cross-sectional study. The study protocol was approved by the University of Ibadan and University College Hospital Health Review Committee (UI/EC/10/0193). Informed consent was obtained from the participants before their recruitment.

Seventy-nine non-pregnant women with histologically confirmed breast cancer were recruited into this study, pre-therapy. Enrolment and basic characteristics of the study participants have previously been reported [11]. Participants were recruited from the Surgical Oncology Clinic of the Department of Surgery, University College Hospital, Ibadan, by a consultant surgical oncologist. Women who reported being on hormonal drugs (i.e., contraceptives and hormone replacement therapy), or had other types of malignancies or chronic diseases, were excluded from the study. Participants were reported as postmenopausal if they were 55 years and older and had stopped menstruating over the last 12 months. Participants with bilateral oophorectomy were considered as postmenopausal

The study participants were then grouped based on their immunohistochemistry results i.e., $69 \mathrm{ER}^{-}$versus $10 \mathrm{ER}^{+} ; 71 \mathrm{PR}^{-}$versus $8 \mathrm{PR}^{+} ; 64 \mathrm{HER}^{-}{ }^{-}$versus $15 \mathrm{HER}-2^{+} ; 17$ postmenopausal $\mathrm{ER}^{-}$versus 10 postmenopausal $\mathrm{ER}^{+} ; 19$ postmenopausal $\mathrm{PR}^{-}$versus 8 postmenopausal $\mathrm{PR}^{+}$; 
46 premenopausal HER-2 ${ }^{-}$versus 6 premenopausal HER $2^{+}$; and 18 postmenopausal HER-2 ${ }^{-}$versus 9 postmenopausal HER-2 ${ }^{+}$.

All the premenopausal participants in the study were ER- and PR-negative. Of the study participants, $83.5 \%$ presented at advanced stages of the disease (stages 3 and 4 ), while 16.5\% of the study participants presented at stages 1 and 2 [11].

\subsection{Sample Collection}

Ten milliliters of venous blood were aseptically obtained by venipuncture from each participant and dispensed into a plain bottle. For premenopausal participants, blood samples were drawn between days five and nine of their menstrual cycle in the follicular phase (forward dating) and five to nine days before the anticipated start of their next menstrual cycle in the luteal phase (backward dating) [10]. All samples were allowed to retract and were centrifuged at $3500 \mathrm{rpm}$ for five minutes. The serum obtained was aspirated into clean vials and stored at $-20^{\circ} \mathrm{C}$ until analyses were done.

\subsection{Hormonal Assay and Toxic Metals Estimation}

Serum progesterone, estradiol $\left(\mathrm{E}_{2}\right)$, luteinizing hormone $(\mathrm{LH}), \mathrm{FSH}$, free triiodothyronine $\left(\mathrm{FT}_{3}\right)$, free thyroxine $\left(\mathrm{FT}_{4}\right)$, and thyroid stimulating hormone (TSH)were determined using enzyme immune assay (EIA) on TOSOH AIA System Analyzers (Tosoh Corporation, Tokyo, Japan). Serum arsenic, cadmium, and lead were determined using atomic absorption spectrophotometry (210 VGP Atomic Absorption Spectrophotometer, Buck Scientific, Norwalk, CT, USA).

\subsection{Statistical Analysis}

Data was analyzed using Statistical Package for Social Scientists (SPSS) software, version 18 (IBM, New York, NY, USA). Mann Whitney U-test was used for the comparison of the non-parametric variables. Multiple regression was used to determine the relationship between variables, with $p$-values less than 0.05 being considered as statistically significant.

\section{Results}

Table 1 shows the serum levels of selected hormones and toxic metals in $\mathrm{ER}^{-}$and $\mathrm{ER}^{+}$breast cancer participants. Estradiol and progesterone were significantly higher in participants with ER ${ }^{-}$ compared with participants with $\mathrm{ER}^{+}$. Moreover, estradiol was significantly higher in postmenopausal participants with $\mathrm{ER}^{-}$compared with postmenopausal participants with $\mathrm{ER}^{+}$. Luteinizing hormone and FSH were significantly higher in participants with $\mathrm{ER}^{+}$compared with participants with $\mathrm{ER}^{-}$. Follicle stimulating hormone was also significantly higher in postmenopausal participants with ER ${ }^{+}$ compared with participants with $\mathrm{ER}^{-}$.

Table 1. Serum levels of hormones and toxicants in ER-negative and ER-positive breast cancer participants.

\begin{tabular}{|c|c|c|c|c|c|c|}
\hline Parameter & $\mathrm{ER}^{-}(n=69)$ & $\mathrm{ER}^{+}(n=10)$ & $\begin{array}{c}\text { Postmeno ER }{ }^{-} \\
\quad(n=17)\end{array}$ & $\begin{array}{l}\text { Postmeno } \mathrm{ER}^{+} \\
\quad(n=10)\end{array}$ & $p_{1}$-value & $p_{2}$-value \\
\hline $\mathrm{E}_{2}(\mathrm{pmol} / \mathrm{L})$ & $\begin{array}{c}295.70 \\
(170.71-480.33)\end{array}$ & $\begin{array}{c}98.66 \\
(82.29-220.79)\end{array}$ & $\begin{array}{c}140.68 \\
(120.60-236.79)\end{array}$ & $\begin{array}{c}95.42 \\
(81.16-193.97)\end{array}$ & $0.001 *$ & $0.038 *$ \\
\hline $\begin{array}{c}\text { Prog } \\
\text { (nmol/L) }\end{array}$ & $2.08(1.33-7.33)$ & $1.29(0.83-1.74)$ & $1.54(1.11-2.50)$ & $1.19(0.82-1.63)$ & $0.010 *$ & 0.153 \\
\hline $\mathrm{LH}(\mathrm{IU} / \mathrm{L})$ & $8.70(4.30-16.40)$ & $24.75(19.60-33.20)$ & $19.20(15.60-34.80)$ & $\begin{array}{c}26.10 \\
(18.60-34.20)\end{array}$ & $0.000 *$ & 0.225 \\
\hline FSH (IU/L) & $8.20(5.18-18.26)$ & 77.77 (53.55-98.85) & $43.70(29.75-58.30)$ & $\begin{array}{c}78.14 \\
(54.20-103.50)\end{array}$ & $0.000 *$ & $0.038 *$ \\
\hline $\mathrm{FT}_{3}(\mathrm{pmol} / \mathrm{L})$ & $3.18(2.75-3.53)$ & $3.30(2.81-3.60)$ & $3.12(2.50-3.54)$ & $3.31(2.79-3.65)$ & 0.585 & 0.666 \\
\hline $\mathrm{FT}_{4}(\mathrm{pmol} / \mathrm{L})$ & $16.96(14.94-20.36)$ & $16.38(15.35-20.26)$ & $17.95(15.83-20.28)$ & $\begin{array}{c}15.84 \\
(15.17-20.48)\end{array}$ & 0.863 & 0.535 \\
\hline $\mathrm{TSH}(\mathrm{mIU} / \mathrm{L})$ & $1.43(0.86-2.37)$ & $1.12(0.83-1.45)$ & $1.54(1.07-1.88)$ & $1.16(0.79-1.70)$ & 0.381 & 0.269 \\
\hline
\end{tabular}


Table 1. Cont.

\begin{tabular}{|c|c|c|c|c|c|c|}
\hline Parameter & $\mathrm{ER}^{-}(n=69)$ & $\mathrm{ER}^{+}(n=10)$ & $\begin{array}{c}\text { Postmeno ER } \\
\quad(n=17)\end{array}$ & $\begin{array}{c}\text { Postmeno ER }{ }^{+} \\
\quad(n=10)\end{array}$ & $p_{1}$-value & $p_{2}$-value \\
\hline $\mathrm{Pb}(\mu \mathrm{g} / \mathrm{dL})$ & $5.22(4.13-6.46)$ & $5.75(5.54-6.88)$ & $5.22(4.21-6.32)$ & $5.82(5.40-7.07)$ & 0.143 & 0.112 \\
\hline $\mathrm{Cd}(\mu \mathrm{g} / \mathrm{dL})$ & $0.04(0.03-0.05)$ & $0.04(0.04-0.05)$ & $0.04(0.03-0.05)$ & $0.05(0.04-0.06)$ & 0.284 & 0.222 \\
\hline As $(\mu \mathrm{g} / \mathrm{dL})$ & $0.27(0.24-0.36)$ & $0.36(0.22-0.42)$ & $0.30(0.25-0.35)$ & $0.40(0.20-0.44)$ & 0.416 & 0.808 \\
\hline
\end{tabular}

Values are in median (interquartile range); $n$, number of subjects; $\mathrm{ER}^{-}$, women with estrogen receptor negative; $\mathrm{ER}^{+}$, women with estrogen receptor positive; Postmeno $\mathrm{ER}^{-}$, postmenopausal women with estrogen receptor negative; Postmeno $\mathrm{ER}^{+}$, postmenopausal women with estrogen receptor positive; Prog, progesterone; $\mathrm{E}_{2}$, estradiol; $\mathrm{LH}$, luteinizing hormone; $\mathrm{FSH}$, follicle stimulating hormone; $\mathrm{FT}_{3}$, free triiodothyronine; $\mathrm{FT}_{4}$, free thyroxine; $\mathrm{TSH}$, thyroid stimulating hormone; IU, international units; $p_{1}$-value, probability between women with $\mathrm{ER}^{-}$and $\mathrm{ER}^{+}$, $p_{2}$-value, probability between postmenopausal women with ER-negative and ER-positive, ${ }^{*}$ significant at $p<0.05$.

As shown in Table 2, estradiol and progesterone were significantly higher in participants with $\mathrm{PR}^{-}$compared with women with $\mathrm{PR}^{+}$. Moreover, estradiol was significantly higher in postmenopausal participants with $\mathrm{PR}^{-}$compared with postmenopausal participants with $\mathrm{PR}^{+}$. Luteinizing hormone and FSH were significantly higher in participants with $\mathrm{PR}^{+}$compared with participants with $\mathrm{ER}^{-}$. Follicle stimulating hormone was also significantly higher in postmenopausal participants with $\mathrm{PR}^{+}$ compared with participants with $\mathrm{PR}^{-}$.

Table 2. Serum levels of hormones and toxicants in PR-negative and PR-positive breast cancer participants.

\begin{tabular}{|c|c|c|c|c|c|c|}
\hline Parameter & $\mathrm{PR}^{-}(n=71)$ & $\mathrm{PR}^{+}(n=8)$ & $\begin{array}{l}\text { Postmeno } \mathrm{PR}^{-} \\
\quad(n=19)\end{array}$ & $\begin{array}{l}\text { Postmeno } \mathrm{PR}^{+} \\
\quad(n=8)\end{array}$ & $p_{1}$-value1 & $p_{2}$-value \\
\hline $\mathrm{E}_{2}(\mathrm{pmol} / \mathrm{L})$ & $\begin{array}{c}290.53 \\
(169.77-477.70)\end{array}$ & $\begin{array}{c}95.42 \\
(81.16-193.97)\end{array}$ & $\begin{array}{c}140.68 \\
(120.60-236.79)\end{array}$ & $\begin{array}{c}95.42 \\
(81.16-193.97)\end{array}$ & $0.000 *$ & $0.038 *$ \\
\hline $\begin{array}{c}\text { Prog } \\
(\mathrm{nmol} / \mathrm{L})\end{array}$ & $2.06(1.31-5.91)$ & $1.19(0.82-1.63)$ & $1.54(1.11-2.50)$ & $1.19(0.82-1.63)$ & $0.010 *$ & 0.153 \\
\hline LH (IU/L) & $8.70(4.20-15.90)$ & $\begin{array}{c}26.10 \\
(18.60-34.20)\end{array}$ & $19.20(15.60-34.80)$ & $\begin{array}{c}26.10 \\
(18.60-34.20)\end{array}$ & $0.000 *$ & 0.225 \\
\hline FSH (IU/L) & $8.30(5.24-19.08)$ & $\begin{array}{c}78.14 \\
(54.20-103.50)\end{array}$ & $43.70(29.75-58.30)$ & $\begin{array}{c}78.14 \\
(54.20-103.50)\end{array}$ & $0.000 *$ & $0.038 *$ \\
\hline $\mathrm{FT}_{3}(\mathrm{pmol} / \mathrm{L})$ & $3.14(2.74-3.49)$ & $3.31(2.79-3.65)$ & $3.12(2.50-3.54)$ & $3.31(2.79-3.65)$ & 0.506 & 0.666 \\
\hline $\mathrm{FT}_{4}(\mathrm{pmol} / \mathrm{L})$ & $16.96(14.87-20.01)$ & $\begin{array}{c}15.84 \\
(15.17-20.48)\end{array}$ & 17.95 (15.83-20.28) & $\begin{array}{c}15.84 \\
(15.17-20.48)\end{array}$ & 0.808 & 0.535 \\
\hline TSH (mIU/L) & $1.47(0.88-2.39)$ & $1.16(0.77-1.70)$ & 1.54 (1.07-1.88) & $1.16(0.79-1.70)$ & 0.385 & 0.269 \\
\hline $\mathrm{Pb}(\mu \mathrm{g} / \mathrm{dL})$ & $5.22(4.13-6.54)$ & $5.82(5.40-7.07)$ & $5.22(4.21-6.33)$ & $5.82(5.40-7.07)$ & 0.152 & 0.112 \\
\hline $\mathrm{Cd}(\mu \mathrm{g} / \mathrm{dL})$ & $0.04(0.03-0.05)$ & $0.05(0.04-0.06)$ & $0.04(0.03-0.05)$ & $0.05(0.04-0.06)$ & 0.280 & 0.222 \\
\hline As $(\mu \mathrm{g} / \mathrm{dL})$ & $0.27(0.24-0.36)$ & $0.4(0.20-0.44)$ & $0.30(0.25-0.35)$ & $0.36(0.20-0.44)$ & 0.583 & 0.808 \\
\hline
\end{tabular}

Values are in median (interquartile range); $n$, number of subjects; $\mathrm{PR}^{-}$, women with progesterone receptor negative; $\mathrm{PR}^{+}$, women with progesterone receptor-positive; Postmeno $\mathrm{PR}^{-}$, postmenopausal women with progesterone receptor-negative; Postmeno $\mathrm{PR}^{+}$, postmenopausal women with progesterone receptor-positive; Prog, progesterone, $\mathrm{E}_{2}$, estradiol; $\mathrm{LH}$, luteinizing hormone; $\mathrm{FSH}$, follicle stimulating hormone; $\mathrm{FT}_{3}$, free triiodothyronine; $\mathrm{FT}_{4}$, free thyroxine; TSH, thyroid stimulating hormone. $p_{1}$-value, probability between women with $\mathrm{PR}^{-}$and $\mathrm{PR}^{+}, p_{2}$-value, probability between postmenopausal women with $\mathrm{PR}^{-}$and $\mathrm{PR}^{+},{ }^{*}$ significant at $p<0.05$.

Progesterone was significantly higher in participants with HER-2 ${ }^{-}$compared with participants with HER-2 ${ }^{+}$, while FSH was significantly higher in participants with ER+ compared with participants with HER-2 ${ }^{-}$(Table 3).

Table 3. Serum levels of hormones and toxicants in HER-2- negative and HER-2 positive breast cancer participants.

\begin{tabular}{cccc}
\hline Parameter & HER-2 $^{-}(\boldsymbol{n}=\mathbf{6 4})$ & HER-2 $^{+}(\boldsymbol{n}=\mathbf{1 5})$ & -value $^{-}$ \\
\hline $\mathrm{E}_{2}(\mathrm{pmol} / \mathrm{L})$ & $251.80(147.30-463.05)$ & $219.64(136.42-376.33)$ & 0.803 \\
Prog $(\mathrm{nmol} / \mathrm{L})$ & $1.80(1.33-6.06)$ & $1.45(0.83-2.69)$ & $0.049^{*}$ \\
$\mathrm{LH}(\mathrm{IU} / \mathrm{L})$ & $9.33(4.60-16.78)$ & $16.60(7.20-22.00)$ & 0.179 \\
\hline
\end{tabular}


Table 3. Cont.

\begin{tabular}{cccc}
\hline Parameter & HER-2 $^{-}(\boldsymbol{n}=\mathbf{6 4})$ & HER-2 $^{+}(\boldsymbol{n}=\mathbf{1 5})$ & $p$-value \\
\hline $\mathrm{FSH}(\mathrm{IU} / \mathrm{L})$ & $8.35(5.35-22.85)$ & $35.20(10.03-77.40)$ & $0.010^{*}$ \\
$\mathrm{FT}_{3}(\mathrm{pmol} / \mathrm{L})$ & $3.19(2.80-3.53)$ & $2.75(2.44-3.45)$ & 0.171 \\
$\mathrm{FT}_{4}(\mathrm{pmol} / \mathrm{L})$ & $17.05(14.96-20.85)$ & $16.64(14.79-17.77)$ & 0.255 \\
$\mathrm{TSH}(\mathrm{mIU} / \mathrm{L})$ & $1.50(0.88-2.35)$ & $1.16(0.85-1.63)$ & 0.446 \\
$\mathrm{~Pb}(\mu \mathrm{g} / \mathrm{dL})$ & $5.53(4.21-6.62)$ & $5.62(3.70-5.99)$ & 0.465 \\
$\mathrm{Cd}(\mu \mathrm{g} / \mathrm{dL})$ & $0.04(0.03-0.05)$ & $0.04(0.03-0.05)$ & 0.335 \\
$\mathrm{As}(\mu \mathrm{g} / \mathrm{dL})$ & $0.30(0.24-0.36)$ & $0.24(0.24-0.34)$ & 0.384 \\
\hline
\end{tabular}

Values are in median (interquartile range); $n$, number of subjects; HER-2 ${ }^{-}$, women with human epithelial receptor-2-negative; $\mathrm{HER}^{+}$, women with human epithelial receptor-2-positive;Postmeno HER-2 ${ }^{-}$, postmenopausal women with human epithelial receptor-2-negative;Postmeno HER-2+, postmenopausal women with human epithelial receptor-2-positive; Prog, progesterone; $\mathrm{E}_{2}$, estradiol; $\mathrm{LH}$, luteinizing hormone; FSH, follicle stimulating hormone; $\mathrm{FT}_{3}$, free triiodothyronine; $\mathrm{FT}_{4}$, free thyroxine; $\mathrm{TSH}$, thyroid stimulating hormone; $p$-value, probability between premenopausal women with HER-2- ${ }^{-}$and HER-2 $2^{+}$; $^{*}$ significant at $p<0.05$.

Table 4 shows the multiple regression of variables. In premenopausal women with $\mathrm{ER}^{-}, \mathrm{PR}^{-}$, and HER-2 ${ }^{-}$, progesterone was positively related with $\mathrm{FT}_{3}$, but inversely related with $\mathrm{TSH}(\beta=0.246$, $\beta=-0.272 ; \beta=0.229, \beta=-0.301 ; \beta=0.650, \beta=-0.677$, respectively). In premenopausal women with $\mathrm{ER}^{-}$and $\mathrm{PR}^{-}$, estradiol was positively related with progesterone and TSH $(\beta=0.724, \beta=0.260$; $\beta=0.843, \beta=0.120$, respectively). Moreover, progesterone was inversely related with arsenic $(\beta=-0.216 ; \beta=-0.188)$. Thyroid stimulating hormone was also inversely related with arsenic $\left(\beta=-0.330 ; \beta=-0.304\right.$, respectively). In premenopausal women with $\mathrm{ER}^{-}, \mathrm{FT}_{4}$ was inversely related with arsenic $(\beta=-0.330)$, while TSH was positively related with FSH $(\beta=0.281)$. In postmenopausal women with $\mathrm{ER}^{-}, \mathrm{PR}^{-}$, and HER-2 ${ }^{-}$, $\mathrm{LH}$ was inversely related with lead $(\beta=-4.843 ; \beta=-4.843$; $\beta=-6.995$, respectively), while LH was positively related with cadmium $(\beta=5.045 ; \beta=5.045$; $\beta=6.803)$. In postmenopausal women with HER-2 ${ }^{-}$, FSH was positively related with $\mathrm{LH}(\beta=0.963)$, while progesterone was positively related with $\mathrm{E}_{2}(\beta=0.896)$.

Table 4. Multiple regression analysis of variables in pre and postmenopausal women with ER-, PR-and HER2-negative breast cancer.

\begin{tabular}{|c|c|c|c|c|}
\hline Group & Dependent & Predictors & $\beta$ & $p$-Value \\
\hline \multicolumn{5}{|l|}{ Premenopausal ER ${ }^{-}$} \\
\hline \multirow{2}{*}{$R^{2}=0.611, \mathrm{~F}=7.686, p=0.000$} & $E_{2}$ & Prog & 0.724 & 0.000 \\
\hline & & TSH & 0.260 & 0.017 \\
\hline \multirow[t]{4}{*}{$R^{2}=0.639, \mathrm{~F}=8.645, p=0.000$} & Prog & $\mathrm{FT}_{3}$ & 0.246 & 0.013 \\
\hline & & TSH & -0.272 & 0.009 \\
\hline & & $\mathrm{E}_{2}$ & 0.673 & 0.000 \\
\hline & & As & -0.216 & 0.033 \\
\hline$R^{2}=0.138, F=0.781, p=0.635$ & $\mathrm{FT}_{4}$ & As & -0.330 & 0.035 \\
\hline \multirow{2}{*}{$R^{2}=0.296, F=2.058, p=0.055$} & TSH & As & -0.305 & 0.030 \\
\hline & & FSH & 0.281 & 0.037 \\
\hline \multicolumn{5}{|l|}{ Postmenopausal ER ${ }^{-}$} \\
\hline \multirow[t]{2}{*}{$R^{2}=0.894, F=6.589, p=0.011$} & LH & $\mathrm{Pb}$ & -4.843 & 0.003 \\
\hline & & $\mathrm{Cd}$ & 5.045 & 0.004 \\
\hline \multicolumn{5}{|l|}{ Premenopausal $\mathrm{PR}^{-}$} \\
\hline \multirow[t]{2}{*}{$R^{2}=0.693, F=10.547, p=0.000$} & $E_{2}$ & TSH & 0.320 & 0.002 \\
\hline & & Prog & 0.843 & 0.000 \\
\hline$R^{2}=0.227, F=1.374, p=0.231$ & $\mathrm{FT}_{3}$ & Prog & 0.655 & 0.010 \\
\hline \multirow[t]{3}{*}{$R^{2}=0.354, F=2.558, p=0.019$} & TSH & As & -0.304 & 0.028 \\
\hline & & Prog & -0.728 & 0.001 \\
\hline & & $\mathrm{E}_{2}$ & 0.673 & 0.002 \\
\hline
\end{tabular}


Table 4. Cont

\begin{tabular}{|c|c|c|c|c|}
\hline Group & Dependent & Predictors & $\beta$ & $p$-Value \\
\hline \multirow{4}{*}{$R^{2}=0.730, F=12.637, p=0.000$} & Prog & As & -0.188 & 0.036 \\
\hline & & $\mathrm{E}_{2}$ & 0.741 & 0.000 \\
\hline & & $\mathrm{FT}_{3}$ & 0.229 & 0.010 \\
\hline & & TSH & -0.301 & 0.001 \\
\hline \multicolumn{5}{|l|}{ Postmenopausal $\mathrm{PR}^{-}$} \\
\hline & LH & $\mathrm{Pb}$ & -4.843 & 0.003 \\
\hline & & $\mathrm{Cd}$ & 5.045 & 0.004 \\
\hline \multicolumn{5}{|l|}{ Premenopausal HER-2- } \\
\hline$R^{2}=0.284, F=1.498, p=0.188$ & $\mathrm{FT}_{3}$ & Prog & 0.650 & 0.009 \\
\hline \multirow[t]{2}{*}{$R^{2}=0.329, F=1.848, p=0.095$} & TSH & Prog & -0.677 & 0.005 \\
\hline & & $\mathrm{E}_{2}$ & 0.685 & 0.003 \\
\hline \multicolumn{5}{|l|}{ Postmenopausal HER-2- } \\
\hline \multirow[t]{3}{*}{$R^{2}=0.839, F=5.777, p=0.006$} & LH & $\mathrm{Pb}$ & -6.995 & 0.000 \\
\hline & & $\mathrm{Cd}$ & 6.803 & 0.000 \\
\hline & & FSH & 0.483 & 0.015 \\
\hline$R^{2}=0.883, F=8.418, p=0.001$ & Prog & $\mathrm{E}_{2}$ & 0.896 & 0.000 \\
\hline$R^{2}=0.679, F=2.346, p=0.100$ & FSH & $\mathrm{LH}$ & 0.963 & 0.015 \\
\hline
\end{tabular}

$B$, Beta coefficient; $F, F$-statistics; $p$-value, probability; $\mathrm{E}_{2}$, estradiol; $\mathrm{LH}$, luteinizing hormone; $\mathrm{FT}_{3}$, triiodothyronine; FSH, follicle stimulating hormone, TSH, thyroid stimulating hormone; ER, estrogen receptor; PR, progesterone receptor; HER-2, human epithelial receptor-2.

\section{Discussion}

Breast cancer is a heterogeneous disease with a wide spectrum of clinical, pathologic, and molecular features [17]. It comprises luminal, HER-2 ${ }^{+}$, and triple negative subtypes [18]. Luminal and HER $-2^{+}$breast cancers are responsive to endocrine and anti-HER-2 therapies, respectively. However, chemotherapy is effective in the management of triple negative breast cancer [19].

Premenopausal breast cancer is a challenge to patients, their family members, and the health care system. It is associated with adverse pathological factors, such as high-grade tumor, presentation at a later stage than their older counterparts, and hormone receptor negativity [20]. The premenopausal women in this study were all $\mathrm{ER}^{-}$and $\mathrm{PR}^{-}$. This is similar to the findings of Makanjuola et al. [21]. The adverse pathological factors that characterize triple negative breast cancer could be the basis of their worse disease outcome. Women with triple negative breast cancer $\left(\mathrm{ER}^{-}, \mathrm{PR}^{-}\right.$and $\left.\mathrm{HER}-2^{-}\right)$in this study may benefit from chemotherapy as the first line of treatment. This is because they lack the appropriate hormone receptors. Participants with luminal breast cancer can, however, benefit from endocrine therapy.

High levels of endogenous steroid hormones, particularly estrogens, are believed to increase breast cancer risk [6]. In this study, estradiol was significantly higher in in breast cancer participants with negative ER and PR expressions, as compared with participants with positive ER and PR expression. A similar observation was also made in the postmenopausal participants in this study. This contrasts with the report of Farhat et al. [22], which showed that there is higher level of estradiol in postmenopausal women with ER+ breast cancer. However, Kim et al. [23] reported a similar observation to our study. They observed that serum estradiol level adversely affect prognosis in patients with ER-negative tumors. Estrogen mediates important cellular activity in estrogen receptor-negative breast cancer cells via membrane associated $G$ protein-coupled receptor 30 (GPR30). This is a non-ER-mediated pathway involving ezrin-dependent cytoskeleton rearrangement, which elicits a stimulatory effect on cell migration and invasion [24]. Gupta et al. [25] observed that estradiol enhanced tumor formation of weakly tumorigenic $\mathrm{ER}^{-}$human mammary epithelial cells (HMLE-Ras) when injected into the mammary fat pad of laboratory animals. This effect was caused by 
the systemic induction of angiogenesis and stromal cell recruitment by estradiol. These observations, together with ours, suggest that estradiol can act as a potent promoter of metastasis in $\mathrm{ER}^{-}$tumors through mechanisms involving the host microenvironment.

The role of estrogen in breast cancer as a potent breast mitogen is undisputed, however, the role of progesterone is grossly understudied [26]. In this study, progesterone was significantly higher in breast cancer participants with $\mathrm{ER}^{-}, \mathrm{PR}^{-}$, and HER-2- (triple negative) breast cancer compared with participants with positive ER, PR, and HER-2 expressions. Primarily, progesterone may act via protooncogenes and growth factors to affect breast cell proliferation and breast cancer etiology [26]. The absence of the appropriate receptors for the hormones could cause the loss of feedback mechanisms in the women with triple negative breast cancer.

Pituitary production of LH and FSH in premenopausal women is controlled by the secretion of gonadotropin releasing hormone $(\mathrm{GnRH})$ from the hypothalamus. After menopause, the pulsatility in gonadotropin secretion is a consequence of a reduced release of hypothalamic GnRH and of a decreased sensitivity of the pituitary gonadotropin [27]. Previous research has linked gonadotropins with breast cancer [28]. In this study, serum LH and FSH levels were significantly higher in participants with positive ER and PR expressions compared with participants who were ER- and PR-negative, respectively. Increased FSH levels were also observed in postmenopausal women with $\mathrm{ER}^{+}$and $\mathrm{PR}^{+}$compared with postmenopausal women with $\mathrm{ER}^{-}$and $\mathrm{PR}^{-}$in this study. Follicle stimulating hormone increases with age and correlates with a loss of ovarian reserve [29]. Our observation suggests that gonadotropins could be involved in the pathogenesis of hormone responsive breast cancers. Tanaka et al. [30] observed that gonadotropin acts on breast cancer cells and accelerates the conversion of dehydroepiandrosterone (DHEA) into estrogens, thereby, stimulating the growth of estrogen-dependent tumorous cells.

Follicle stimulating hormone levels were significantly higher in women with HER-2 ${ }^{+}$breast cancer compared with HER-2 $2^{-}$breast cancer in this study. This aligns with the reports of Zhou et al. [31]. Human epithelial receptor-2-positive breast cancer grows faster, spreads rapidly, has increased risk of loco-regional recurrence, and increases breast cancer mortality [32,33]. Observations from this study indicate that FSH could be involved in the proliferation of HER-2 ${ }^{+}$breast cancer. This could be via mechanisms involving tyrosine kinase, which drives the proliferation of cells and evasion of apoptosis, genetic, and epigenetic modifications, as well as alterations in upstream regulators, such as the fox headbox p3 (Fox p3) and GATA4 [34].

Changes in thyroid hormone levels have been associated with proliferative activity of breast cancer [35]. In this study, there was no difference in the thyroid hormone levels in the premenopausal and postmenopausal women with positive and negative hormone receptors. However, a positive relationship was observed between $\mathrm{E}_{2}$ and TSH in premenopausal participants who were ER- and PR-negative. The biological activity of thyroid hormones and estradiol manifests in cells expressing their respective receptors, which belong to the nuclear receptor family. Moreover, estrogen-like effects of thyroid hormones have been reported [36]. Progesterone was positively related with $\mathrm{FT}_{3}$, but inversely related with TSH in premenopausal participants with triple negative breast cancer. This relationship was not observed in postmenopausal participants. The reason for this observation is not clear, but suggests an interplay between progesterone and thyroid hormones in the pathogenesis of non-hormone responsive breast cancer.

Studies have suggested an association between exposure to heavy metals and carcinogenesis $[37,38]$. In this study, there were no differences in the serum lead, cadmium, and arsenic between women with positive hormone receptors and negative hormone receptors. However, an inverse relationship was observed between TSH and arsenic in premenopausal women with $\mathrm{ER}^{-}$and $\mathrm{PR}^{-}$breast cancer. Arsenic is a potent endocrine disruptor, which has been associated with malignancies. Davey et al. [39] observed an interference of thyroid hormone metabolism by arsenic. One hypothesized mechanism of thyroid hormone disruption is through the affection of the thyroid receptor (TR) response elements and the expression of type 1 deiodinase gene [40]. In addition, the inverse relationship of progesterone 
with arsenic also suggests the possible interference of progesterone metabolism by arsenic, which could result in breast carcinogenesis.

Lead and cadmium can cross the blood-brain barrier and, thereby, disrupt the hypothalamic-pituitary axis [41]. In postmenopausal women with $\mathrm{ER}^{-}$and $\mathrm{PR}^{-}$, a positive relationship was observed between cadmium and LH. This buttresses the endocrine disrupting property of Cd, although, the mechanism through which this is carried out is poorly understood at present.

\section{Conclusions}

Findings from this study suggest that estradiol and progesterone may be involved in the pathogenesis of triple negative breast cancer, while gonadotropins may be involved in luminal breast carcinogenesis

\section{Study Limitation}

Small sample size was a limitation in this study, therefore, studies with a large sample size are suggested to substantiate our findings.

Author Contributions: All authors designed the work. O.A. did the laboratory and statistical analysis. O.A. and A.A. recruited study participants. O.A. and M.C.-D. wrote the first draft. All authors approved the final draft of the manuscript.

Funding: This research received no external funding.

Acknowledgments: The authors appreciate the staff of Genetics and Bioethics Laboratory, Institute for Advanced Medical Research and Training (IAMRAT), University of Ibadan for the immunohistochemical analysis.

Conflicts of Interest: Authors declare no conflict of interest.

\section{References}

1. Onitilo, A.; Engel, J.M.; Greenlee, T.R.; Mukesh, B.N. Breast cancer subtypes based on estrogen receptor, progesterone receptor and human epithelial receptor 2 expression. Comparison of clinicopathologic features and survival. Clin. Med. Res. 2009, 7, 4-13. [CrossRef] [PubMed]

2. Badve, S.S.; Baehner, F.L.; Gray, R.P.; Childs, B.H.; Maddala, T.; Liu, M.L.; Rowley, S.C.; Shak, S.; Perez, E.A.; Shulman, L.J.; et al. Estrogen and progesterone receptors status in ECOG 2197; Comparison of immunohistochemical by local and central laboratories and quantitative reverse transcription polymerase chain reaction by central Laboratory. J. Clin. Oncol. 2008, 26, 2473-2481. [CrossRef] [PubMed]

3. Brown, M.; Tsodikov, A.; Bauer, K.R.; Parise, C.A.; Caggiano, V. The role of human epithelial growth factor receptor 2 in the survival of women with estrogen and progesterone receptor negative, invasive breast cancer. The California cancer registry 1999-2004. Cancer 2008, 112, 737-747. [CrossRef] [PubMed]

4. Umayahara, Y.; Kawamori, R.; Watada, H.; Imano, E.; Iwama, N.; Morishima, T.; Yamasaki, Y.; Kajimoto, Y.; Kamada, T. Estrogen regulation of the insulin-like growth factor 1 gene transcription involves and AP-1 enhancer. J. Biol. Chem. 1994, 269, 16433-16442. [PubMed]

5. Horwitz, K.B.; Jackson, T.A.; Bain, D.L.; Richer, J.K.; Takimoto, G.S.; Tung, L. Nuclear receptor co-activators and co-repressors. Mol. Endocrinol. 1996, 10, 1167-1177. [PubMed]

6. Ho, C.C.K.; Rohaizak, M.; Zulkifli, S.Z.; Siti-Aishah, M.A.; Nor-Aini, U.; Sharifah-Noor-Akmal, S.H. Serum sex hormone levels in pre and postmenopausal breast cancer patients. Singap. Med. J. 2009, 50, 513-518.

7. Russo, I.H.; Russo, J. Role of hormones in mammary cancer initiation and progression. J. Mammary Gland Biol. Neoplast. 1998, 3, 349-361.

8. Brisken, C. Endocrine disruptors and breast cancer. Chimia 2008, 62, 406-409. [CrossRef]

9. Yager, J.D.; Davidson, N.E. Mechanisms of disease: Estrogen carcinogenesis in breast cancer. N. Engl. J. Med. 2006, 354, 270-282. [CrossRef] [PubMed]

10. Wang, B.; Mi, M.; Wang, J.; Wei, N.; Zhang, Q.; Zhu, J.; Yang, S.; Guo, B.; Xu, J.; Yang, X. Does the increase of endogenous steroid hormone levels also affect breast cancer risk in Chinese women? A case-control study in Chongqing, China. Int. J. Cancer 2009, 124, 1892-1899. [CrossRef] [PubMed] 
11. Ajayi, O.; Charles-Davies, M.; Anetor, J.; Adeyinka, A. Sex hormones, oestrogen receptor, progesterone receptor and human epithelial receptor 2 expressions in pre and postmenopausal sub-Saharan African women with breast cancer. J. Cancer Tumour Int. 2016, 3, 1-11. [CrossRef]

12. Tunizicker-Dun, M.; Maizels, E.T. FSH signaling pathways in immature granulose cells that regulate target gene expression; branching out from protein kinase A. Cell Signal. 2006, 18, 1351-1359.

13. Fan, H.Y.; Cheng, X.; Richards, J.S. FSH induces multiple signaling cascades; evidence that activation of Rous sarcoma oncogene RAS and epidermal growth factor receptor are critical for differentiation. Mol. Endocrinol. 2007, 21, 1940-1957.

14. Tosovic, A.; Bondesson, A.G.; Bonseson, L.; Ericsson, U.B.; Malm, J.; Manjer, J. Prospectively measured triiodothyronine levels are positively associated with breast cancer risk in postmenopausal women. Breast Cancer Res. 2010, 12, R33. [CrossRef] [PubMed]

15. Tosovic, A.; Becker, C.; Bondeson, A.G.; Ericsson, U.B.; Malm, J.; Manjer, J. Prospectively measured thyroid hormone and thyroid peroxidase antibodies in relation to breast cancer risk. Int. J. Cancer 2012, 131, 2126-2133. [CrossRef] [PubMed]

16. Rossner, P., Jr.; Gammon, M.D.; Terry, M.B.; Agrawal, M.; Zhang, F.F.; Teitelbaum, S.L.; Eng, S.M.; Gaudet, M.M.; Neugut, A.I.; Santella, R.M. Relationship between urinary 15-F2t- Isoprostane and 8-Oxodeoxyguanosine levels and breast cancer risk. Cancer Epidemiol. Biomark. Prev. 2006, 15, 639-644. [CrossRef] [PubMed]

17. Parise, C.A.; Caggiano, V. Breast cancer survival defined by estrogen receptor, progesterone receptor and human epithelial receptor 2 subtypes and a surrogate classification according to tumour grade and immunohistochemical biomarkers. J. Cancer Epidemiol. 2014, 2014, 469251. [CrossRef] [PubMed]

18. Perou, C.M.; Sorlie, T.; Eisen, M.B.; van de Rijn, M.; Jeffrey, S.S.; Rees, C.A.; Pollack, J.R.; Ross, D.T.; Johnsen, H.; Akslen, L.A.; et al. Molecular portraits of human breast tumors. Nature 2000, 406, 747-752. [CrossRef] [PubMed]

19. Cardoso, F.; Costa, A.; Senkus, E.; Aapro, M.; Andre, F.; Barrios, C.H.; Bergh, J.; Bhattacharyya, G.; Biganzoli, L.; Cardoso, M.J.; et al. 3rd ESO-ESMO International Consensus Guidelines for Advanced Breast Cancer (ABC 3). Ann. Oncol. 2017, 28, 16-33. [CrossRef] [PubMed]

20. Assi, H.A.; Khoury, K.E.; Dbouk, H.; Khalil, L.E.; Mouhieddine, T.H.; El Saghir, N.S. Epidemiology and prognosis of breast cancer in young women. J. Thorac. Dis. 2013, 5, S2-S8. [PubMed]

21. Makanjuola, S.B.L.; Ayodele, S.D.; Javid, F.A.; Obafunwa, J.O.; Oludara, M.A.; Popoola, A.O. Breast cancer receptor status assessment and clinicopathological association in Nigerian women: A retrospective analysis. J. Cancer Res. Therapy 2014, 2, 122-127.

22. Farhat, G.N.; Cummings, S.R.; Chlebowski, R.T.; Parimi, N.; Cauley, J.A.; Rohan, T.E.; Huang, A.J.; Vitolins, M.; Hubbell, F.A.; Manson, J.E.; et al. Sex hormone levels and risk of estrogen receptor negative and estrogen positive breast cancer. J. Natl. Cancer Inst. 2011, 103, 562-570. [CrossRef] [PubMed]

23. Kim, J.Y.; Han, W.; Moon, H.G.; Ahn, S.K.; Kim, J.; Lee, J.W.; Kim, M.K.; Kim, T.; Noh, D.Y. Prognostic effects of preoperative serum estradiol level in postmenopausal breast cancer. BMC Cancer 2013, 13, 503. [CrossRef] [PubMed]

24. Zhou, K.; Sun, P.; Zhang, Y.; You, X.; Li, P.; Wang, T. Estrogen stimulated migration and invasion of estrogen receptor negative breast cancer cells involves ezrin-dependent cross talk between $G$ protein-coupled receptor 30 and estrogen receptor beta signaling. Steroids 2016, 111, 113-120. [CrossRef] [PubMed]

25. Gupta, P.B.; Proia, D.; Cingoz, O.; Weremowics, J.; Naber, S.P.; Weinberg, R.A.; Kuperwasser, C. Systemic stromal effects of estrogen promote the growth of estrogen receptor negative cancers. Cancer Res. 2007, 67, 2062-2071. [CrossRef] [PubMed]

26. Lange, C.A.; Yee, D. Progesterone and breast cancer. Women's Health 2008, 4, 151-162. [CrossRef] [PubMed]

27. Rossmanith, W.G.; Scherbaum, W.A.; Lauritzen, C. Gonadotropin secretion during aging in postmenopausal women. Neuroendocrinology 1991, 54, 211-218. [CrossRef] [PubMed]

28. Siraj, A.; Desestret, V.; Antoine, M.; Fromont, G.; Huerre, M.; Sanson, M. Expression of FSHR by the vascular endothelium in tumour metastasis. BMC Cancer 2013, 13, 246. [CrossRef] [PubMed]

29. Rojas, L.V.; Nieves, K.; Suarez, E.; Ortiz, A.P.; Rivera, A.; Romaguera, J. Thyroid-stimulating hormone and follicle-stimulating hormone status in Hispanic women during the menopause transition. Ethn. Dis. 2008, 18, S2-230-4. [PubMed] 
30. Tanaka, Y.; Kuwabara, K.; Okazaki, T.; Fujita, T.; Oizumi, I.; Kaiho, S.; Ogata, E. Gonadotropins stimulate growth of MCF-7 human breast cancer cells by promoting intracellular conversion of adrenal androgen to estrogens. Oncology 2000, 59, 19-23. [CrossRef] [PubMed]

31. Zhou, J.; Chen, Y.; Huang, Y.; Long, J.; Wan, F.; Zhan, S. Serum follicle stimulating hormone level is associated with human epidermal growth factor receptor type 2 and Ki67 expression in postmenopausal females with breast cancer. Oncol. Lett. 2013, 6, 1128-1132. [CrossRef] [PubMed]

32. Arvold, N.D.; Taghian, A.G.; Niemierko, A.; Abi Raad, R.F.; Sreedhara, M.; Nguyen, P.L.; Bellon, J.R.; Wong, J.S.; Smith, B.L.; Harris, J.R. Age, Breast Cancer Subtype Approximation, and Local Recurrence After Breast-Conserving Therapy. J. Clin. Oncol. 2011, 29, 3885-3891. [CrossRef] [PubMed]

33. Voduc, K.D.; Cheang, M.C.; Tyldesley, S.; Gelmon, K.; Nielsen, T.O.; Kennecke, H. Breast cancer subtypes and the risk of local and regional relapse. J. Clin. Oncol. 2010, 28, 1684-1691. [CrossRef] [PubMed]

34. Dixon, J.M. Endocrine Resistance in Breast Cancer. New J. Sci. 2014, 2014, 390618. [CrossRef]

35. Mourouzis, I.; Tzovaras, A.; Armonis, B.; Ardavanis, A.; Skondra, M.; Misitzis, J.; Pectasides, D.; Pantos, C. Are thyroid hormone and tumor cell proliferation in human breast cancers positive for HER2 associated? Int. J. Endocrinol. 2015, 2015, 765406. [CrossRef] [PubMed]

36. Ali, A.; Mir, M.; Bashir, S.; Hassan, T. Impact of serum thyroid hormones and estrogen status on the risk of breast cancer in Kashmiri women. J. Cell Sci. Ther. 2011, 2, 113. [CrossRef]

37. Ying, S.; Myers, K.; Bottomley, S.; Helleday, T.; Bryant, H.E. BRCA2- dependent homologous recombination is required for repair of Arsenite-induced replication lesions in mammalian cells. Nucleic Acid Res. 2009, 37, 5103-5113. [CrossRef] [PubMed]

38. Xu, Y.; Tokar, E.J.; Waalkes, M.P. Arsenic-induced cancer cell phenotype in human breast epithelia is estrogen receptor-independent but involves aromatase activation. Arch. Toxicol. 2014, 88, 263-274. [CrossRef] [PubMed]

39. Davey, J.C.; Nomikos, A.P.; Wungjiranirun, M.; Sherman, J.R.; Ingram, L.; Batki, C.; Lariviere, J.P.; Hamilton, J.W. Arsenic as an endocrine disruptor: Arsenic disrupts retinoic acid receptor and thyroid hormone receptor-mediated gene regulation and thyroid hormone mediated amphibian tail metamorphosis. Environ. Health Perspect. 2008, 116, 165-172. [CrossRef] [PubMed]

40. Sun, H.J.; Xiang, P.; Luo, J.; Hong, H.; Lin, H.; Li, H.B.; Ma, L.Q. Mechanisms of arsenic disruption on gonadal, adrenal and thyroid endocrine systems in humans: A review. Environ. Int. 2016, 95, 61-68. [CrossRef] [PubMed]

41. Klein, D.; Wan, Y.J.; Kamyab, S.; Okuda, H.; Sokol, R.Z. Effects of toxic levels of lead on gene regulation in the male axis: Increase in mRNA and intracellular stores of gonadotrophs within the central nervous system. Biol. Reprod. 1994, 50, 802-811. [CrossRef] [PubMed] 